\title{
水熱法により得られた水酸アパタイトナノ結晶の タンパク質吸着特性及び抗菌性
}

\author{
笠原英充・小形信男 ·荻原 隆 \\ 福井大学大学院工学研究科ファイバーアメニティ工学専攻, 910-8507 福井市文京 3-9-1

\section{Protein Adsorption and Antibacterial Behavior for Hydroxyapatite Nanocrystals Prepared by Hydrothermal Method}

\author{
Hidemitsu KASAHARA, Nobuo OGATA and Takashi OGIHARA \\ Graduate School of Fiber Amenity Engineering, Fukui University, 3-9-1, Bunkyo, Fukui-shi 910-8507
}

\begin{abstract}
Homogeneous hydroxyapatite nanocrystals which have aspect ratio with more than four were synthesized by hydrothermal method. $X$-ray fluorescence analysis revealed that the $\mathrm{Ca} / \mathrm{P}$ ratio of hydroxyapatite nanocrystals was maintaining start composition. The protein adsorption properties and bacteria-resistant of hydroxyapatite nanocrystals were investigated. The protein adsorption properties of hydroxyapatite nanocrystals were improvement after the hydrothermal treatment. Bacteria-resistant behavior of hydroxyapatite nanocrystals was not observed, however, multiplication of bacteria was not observed, either.
\end{abstract}

[Received December 27, 2004; Accepted April 21, 2005]

Key-words : Hydroxyapatite, Nanocystal, Hydrothermal, Protein, Bacteria-resistant

\section{1. 緒 言}

水酸アパタイト（以下 $\left.\mathrm{HAp}: \mathrm{Ca}_{10}\left(\mathrm{PO}_{4}\right)_{6}(\mathrm{OH})_{2}\right)$ はリン酸カ ルシウム化合物の中でも生体親和性に優れており，その特徵的 な吸着作用は，クロマトグラフィー用カラム充填剤や各種固定 担体として応用されている1 .HAp の吸着作用は医用分野でも 注目されており，歯垢を吸着させる歯磨材や酵素等を徐放する 生体埋入材料などへの適用が期待されている2).

上記の各種用途に要求される HAp 粒子としては粒子径がナ ノオーダーで，かつ，結晶相の制御が重要であると考えられ る. ところで HAp の合成方法には, 湿式法, 水熱法, 加水分 解法や乾式法などが挙げられ, 特に, 水熱法は, $c$ 軸成長したウ イスカー状あるいは柱状の, HAp 単結晶が得られやすく 32,4$)$, 著者らも過去に水熱法による原料因子と結晶形態の影響に関し て既に報告している5 . また，水熱法は，結晶学的異方性を積極 的に活用しやすく, $\mathrm{Ca}^{2+}$ と錯体形成しやすいクエン酸等の有 機物の添加や6) ${ }^{6}, \mathrm{Ca}^{2+}$ 以外の陽イオンを添加した際のイオン交 換性など，成長プロセス中での相互関係の検討がなされている が7), 共存される種類や量などの複合的な要素の解明には課題 が多いのも事実である。本研究では，水熱合成法で得られた HAp ナノ結晶のアルブミン吸着特性及び抗菌特性について検 討し，吸着特性と複合的な因子について報告する。

\section{2. 実験方法}

\section{1 水酸アパタイトナノ結晶の調製及び評価}

リン酸カルシウム粒子の合成はつぎのと抢りである. $20^{\circ} \mathrm{C} に$ 保持したステンレス製容器中で塩化カルシウム $\left(\mathrm{CaCl}_{2}\right)$ 水溶 液に，リン酸-水素ナトリウム $\left(\mathrm{Na}_{2} \mathrm{HPO}_{4}\right)$ 水溶液をローラー ポンプにより $30 \mathrm{~min}$ で滴下した。滴下中の $\mathrm{pH}$ は6.5〜 7.5の範 囲になるように水酸化ナトリウムで調整した，滴下終了後，更 に $1 \mathrm{~h}\left(20^{\circ} \mathrm{C}\right)$ 熟成を行った。混合中のかくはん速度は $270 \mathrm{rpm}$ とし, 塩化カルシウム及びリン酸-水素ナトリウムのモル比は 1.67になるようにし，濃度は混合後で $1 \mathrm{M}$ になるようにした。 得られた白色のスラリーはオートクレーブ中で $120^{\circ} \mathrm{C}-12 \mathrm{~h}$ 水熱
処理と $150^{\circ} \mathrm{C}-12 \mathrm{~h}$ 水熱処理を 2 系統行い, 処理後, 生成物を沪 過した後，水洗して試料を得た。

生成後の HAp ナノ結晶の状態は, FT-IR（FT/IR-410, 日 本分光製）及び粉末 $\mathrm{X}$ 線回折装置（XRD, M3X，マックサイ エンス製）で検討した．HApナノ結晶における $\mathrm{Ca} / \mathrm{P}$ の組成 比や純度は, 蛍光 X 線分析 (EDX, JSM-5610, JEOL) と原子 吸光光度計（AA-6800，島津製作所製）により求めた. HAp ナノ結晶の比表面積（SSA）はBET 法（NOVA2000，ユアサ 製）により求めた。 HAp ナノ結晶の水中での表面電位は電気 泳動法（ゼータ電位，ゼータサイザーナノ ZS, Malvern）によ り求めた。 HAp ナノ結晶を水中に浸漬し，その水の $\mathrm{pH}$ は, ハンディ $\mathrm{pH}$ 計（pH81-11，横河電機製）により求めた. HAp ナノ結晶の形態は透過型電子顕微鏡（TEM: FX-2000, JEOL） を用いて観察した。 HAp ナノ結晶の平均粒径及びアスペクト 比は TEM 写真から200個の粒子を無作為に抽出して求めた。

\section{2 タンパク質吸着特性}

タンパク質には牛血清アルブミン (BSA: Bovine Serum Albumin）を用い, $1.0 \mathrm{~g} / \mathrm{L}$ 濃度の BSA 溶液を調製した。 $200 \mathrm{ml}$ の BSA 溶液中に試料を $2.0 \mathrm{~g}$ 投入し, かくはんした後, $37^{\circ} \mathrm{C}$ の ンキュベーターに静置した．溶液中のタンパク質濃度を BioRad Protein Assayによる Bradford 法にて吸光光度計（Maltiskan JX, Thermo）を使用して測定（ $\lambda=525 \mathrm{~nm} ）$ した。測定 は試料浸漬後, $0 \sim 72 \mathrm{~h}$ の範囲で行った。 また, 試料未添加 (Control) との吸着効果の比較を行った.

\section{3 抗菌性}

水熱処理前後の試料を $16 \mathrm{~mm} \phi \times 3 \mathrm{~mm}$ の円盤状に加圧形成し たものを測定試料とした。 $12 \mathrm{~h}$ 培養後の口腔内の代表的なウ蝕 菌（Streptococcus mutans $\mathrm{MT}^{8148}$ ) の懸濁液を希釈した $3 \mathrm{~mL}$ の細胞懸濁液 $\left(4 \times 10^{7}\right.$ cells $\left./ \mathrm{mL}\right)$ 中に試料を投入した。 $37^{\circ} \mathrm{C}$ で $1 \mathrm{~h}$ 及び $3 \mathrm{~h}$ 静置培養した後, おのおのの懸濁液を希釈し， MSB (Mitis-Salvarius Bactracin) 寒天培養血にプレーディング

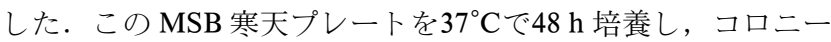
の形成を計測した。本実験では，この試験を 3 回繰り返した. 
また，試料末添加（Control）との吸着効果の比較を行った.

\section{3. 結果及び考察}

\subsection{HAp 粒子の粒子特性}

得られた HAp ナノ結晶の水熱処理前後の XRD と IR スペク トルから, 水熱処理前の結晶性は非常に低いものの, HAp が 生成していることが分かった。水熱処理後, HApナノ結晶 の結晶性は著しく向上していることが分かった．XRDから は HAp 相以外の結晶相は観察されなかった。また，IRから $\mathrm{CO}_{3}{ }^{2-}$ 起因 $\left(870 \mathrm{~cm}^{-1}\right)$ の吸収が水熱処理前後ともわずかに確 認された. 図 1 に水熱処理前後の HAp ナノ結晶の TEM 写真 を示す. 水熱処理後の HAp 粒子は, 電子線回折から明確なス ポットが観察され，ほぼ単結晶であることが分かった．ナノ結 晶の TEM 観察から求めた生成粒子の平均粒径及びその他の物 性を表 1 に示す. 水熱処理後, HAp ナノ結晶のアスペクト比 は 4 以上となり， $c$ 軸に成長していることが分かる. BET 法か ら求めた HAp ナノ結晶の比表面積は $122 \mathrm{~m}^{2} / \mathrm{g}$ であったが, $120^{\circ} \mathrm{C}, 150^{\circ} \mathrm{C}$ 水熱処理後では，それぞれ $61 \mathrm{~m}^{2} / \mathrm{g}$ と $42 \mathrm{~m}^{2} / \mathrm{g}$ ま で減少していることが分かった。 また, 蛍光 X 線分析により 求めた $\mathrm{HAp}$ 粒子の $\mathrm{Ca} / \mathrm{P}$ 比は, $1.65\left(120^{\circ} \mathrm{C}\right)$ と $1.67\left(150^{\circ} \mathrm{C}\right)$ (a) Before hydrothermal

(a) treatment

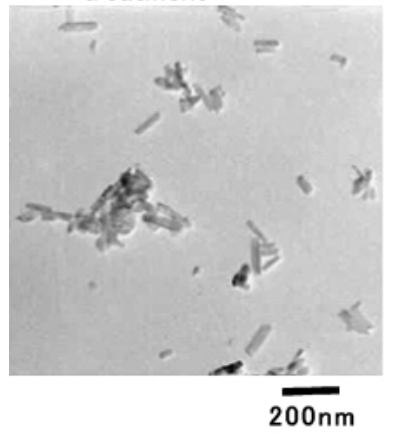

(c)

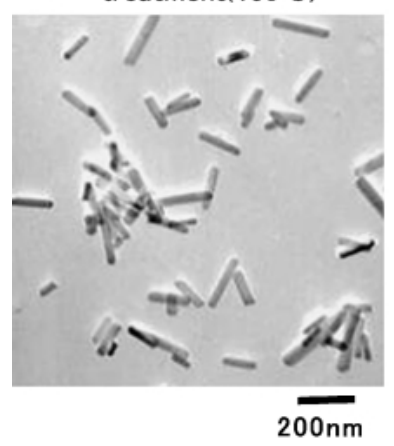

(b) After hydrothermal

(b) treatment $\left(120^{\circ} \mathrm{C}\right)$

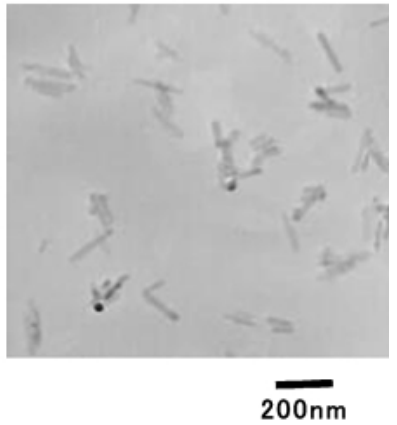

Fig. 1. TEM photographs of HAp nanocrystals prepared by hydrothermal method using the aqueous solution of $\mathrm{CaCl}_{2}-$ $\mathrm{Na}_{2} \mathrm{HPO}_{4}-\mathrm{NaOH}$.
であることから，ほぼ出発組成を維持していた。

\section{2 タンパク質吸着特性及び抗菌効果}

水熱処理前後の HAp ナノ結晶に打けるタンパク質吸着特性 の変化を図 2 に示す。 $c$ 軸成長した HAp ナノ結晶の BSA 吸着 特性は, 水熱処理前と比較すると高いことが分かる. タンパク 質の吸着には, 多くの因子が複雑に関与していると考えられて いるが，BSAの性質としてカルボキシル基 $(-\mathrm{COOH})$ が存在 するため，負の電荷を示すと考えられている．水熱合成後の HAp 粒子は， $c$ 軸に成長していることから，Ca 原子により構 成される $a$ 面（Ca サイト）の表面積の占める割合が, 酸素原 子により構成される $c$ 面 (P サイト)より増大する.このため, 正の電荷を示す $\mathrm{Ca}$ 原子と結晶表面で静電気的な相互作用する 面積が増大することにより, 水熱処理後の HAp は高い BSA 吸 着性を示すものと考えられる ${ }^{8,9)}$. 一方, 水熱処理後の比表面 積（表 1) は約 $1 / 2 \sim 1 / 3$ に減少していることから， タンパク 吸着に対して一般的にいわれる物理的因子（ファンデルワール ス吸着）の影響は, 静電気的な相互作用より少ないものと推察 される。また，IR スペクトルによる $\mathrm{CO}_{3}{ }^{2-}$ 起因の吸収量は, 水熱前後であまり変化していないことから, 含有 $\mathrm{CO}_{3}{ }^{2-}$ と夕 ンパク吸着との関連性は把握することができなかった ${ }^{10)}$ 。一 方, ゼータ電位の值（表 1）は，水熱処理前はほぼ等電点であ るのに対し, 水熱処理後は負に帯電している傾向を示してい た. また, $\mathrm{HAp} ナ ノ$ 粒子中での, $\mathrm{Ca}^{2+}$ のイオン半径 (0.099 $\mathrm{nm}$ ) が似た值である $\mathrm{Na}^{+}$(イオン半径 $0.097 \mathrm{~nm}$ ) の存在量 （表 1）が，水熱処理後には著しく減少していた. HAp の溶解 度は, 溶解度積 $\mathrm{Ksp}\left(=\left[\mathrm{Ca}^{2+}\right]^{10} \cdot\left[\mathrm{PO}_{4}{ }^{3-}\right]^{6} \cdot\left[\mathrm{OH}^{-}\right]^{2}\right)$ に束縛さ れるため, 水熱合成により, $\mathrm{Ca} / \mathrm{P}$ のモル比が高くなるほど, $\mathrm{PO}_{4}{ }^{3-}$ の溶出量も当然増えると考えられる.これは, 水熱後の $\mathrm{pH}$ がわずかながら酸性側に傾いたことにも一致し，ゼータ電 位值がマイナス側へ傾いたものと考えられる.

以上のことから，水熱法による $\mathrm{HAp}$ ナノ粒子の $\mathrm{Ca} / \mathrm{P}$ モル

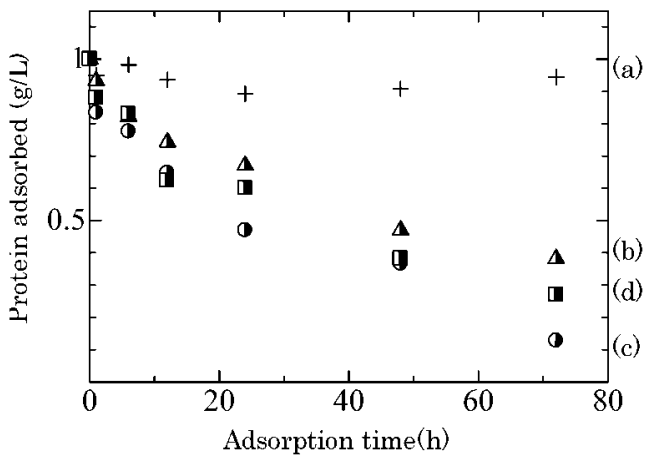

Fig. 2. Protein adsorption capacity of HAp nanocrystals prepared by hydrothermal method using the aqueous solution of $\mathrm{CaCl}_{2}-$ $\mathrm{Na}_{2} \mathrm{HPO}_{4}-\mathrm{NaOH}$.

a) Control, b) before hydrothermal treatment, c) after hydrothermal treatment at $120^{\circ} \mathrm{C}$, d) after hydrothermal treatment at $150^{\circ} \mathrm{C}$.

Table 1. Particle Size, Ca/P Ratio, Na Content, SSA and Zeta Potential of HAp Nanocrystals Prepared by Hydrothermal Method

\begin{tabular}{|l|c|c|c|c|c|}
\hline & $\begin{array}{c}\text { caxial /aaxial } \\
(\mathrm{nm})\end{array}$ & $\mathrm{Ca} / \mathrm{P}$ & $\begin{array}{c}\mathrm{Na} \\
(\mathrm{ppm})\end{array}$ & $\begin{array}{c}\text { SSA } \\
\left(\mathrm{m}^{2} / \mathrm{g}\right)\end{array}$ & $\begin{array}{c}\text { Zeta potential } \\
(\mathrm{mv})\end{array}$ \\
\hline (a)Before Hydrothermal & - & 1.56 & 8700 & 122 & $-0.8(\mathrm{pH} 6.6)$ \\
(b)After Hydrothermal $\left(120^{\circ}\right)$ & $90 / 22$ & 1.63 & 260 & 61 & $-10.3(\mathrm{pH} 6.2)$ \\
(c) $\Delta$ fter Hydrothermal $\left(\mathbf{1 5 0}^{\circ} \mathrm{C}\right)$ & $135 / 24$ & 1.67 & 80 & 42 & $-10.3(\mathrm{pH} 6.2)$ \\
\hline
\end{tabular}


Table 2. Bacteria-Resistant Properties of HAp Nanocrystals Prepared by Hydrothermal Method

\begin{tabular}{|c|c|c|}
\hline & 1 hour after & 3 hour after \\
\hline Control & $5.9 \times 10^{7} / \mathrm{mL}$ & $3.1 \times 10^{8} / \mathrm{mL}$ \\
(a) Before Hydrothermal & $7.5 \times 10^{7} / \mathrm{mL}$ & $1.8 \times 10^{8} / \mathrm{mL}$ \\
(b) After Hydrotherma $\left(120^{\circ} \mathrm{C}\right)$ & $5.3 \times 10^{7} / \mathrm{mL}$ & $1.7 \times 10^{8} / \mathrm{mL}$ \\
(c) After Hydrotherma $\left(150^{\circ} \mathrm{C}\right)$ & $5.1 \times 10^{7} / \mathrm{mL}$ & $1.7 \times 10^{8} / \mathrm{mL}$ \\
\hline
\end{tabular}

比の増大は, 表面電位や電気的な吸着特性に影響を与えると考 えられる11).

水熱処理により得た HAp ナノ結晶の吸着特性を, 細菌への 応用についても検討してみた．表 2 に抗菌生の結果を示す。 表 2 より, 水熱処理前後で抗菌性に有意差は見受けられなかっ た.しかしながら，一般的に HAp は細菌との親和性があると いわれており ${ }^{12)}$, 抗菌試験で菌が増殖する場合もあるが，今回 の菌試験では Control と比較し，そのような増殖は観察されな かった。

\section{4. 結 論}

水熱法により $c$ 軸に成長した水酸アパタイトナノ結晶を合成 し, タンパク質吸着特性及び抗菌効果について検討した。 その 結果, 以下の知見が得られた.

（1）水熱法によりアスペクト比が 4 以上の HAp ナノ結晶が 得られた.
（2）水熱処理により HAp ナノ結晶のアルブミンの吸着特性 が向上した。

（3） HAp ナノ結晶は，水熱処理による抗菌効果は観察され なかったが，菌の増殖も観察されなかった。

\section{References}

1) Narasarajyu, T. S. B. and Phebe, D. E., J. Mater. Sci., Vol. 31, pp. 1-21 (1996).

2) Otuka, M., Seitai Zairyo, Vol. 14, pp. 224-229 (1996) [in Japanese].

3) Ioku, K., Yoshimura, M. and Sōmiya, S., J. Chem. Soc. Jpn., Vol. 9, pp. 1565-1570 (1988) [in Japanese].

4) Asaoka, N., Suda, H. and Yoshimura, M., J. Chem. Soc. Jpn., Vol. 1, pp. 25-29 (1995) [in Japanese].

5) Kasahara, H., Ogata, N. and Ogihara, T., J. Ceram. Soc. Japan, Vol. 112, pp. 650-654 (2004) [in Japanese].

6) Yoshimura, M., Suda, H., Okamoto, K. and Ioku, K., J. Mater. Sci., Vol. 29, pp. 3399-3402 (1994).

7) Aizawa, M., Kinoshita, M., Yamada, K., Itatani, K. and Kishioka, A., Inoganic Materials, Vol. 5, pp. 387-397 (1998) [in Japanese].

8) Ohta, K., Monma, H. and Kawasaki, T., Inoganic Materials, Vol. 6, pp. 224-230 (1999) [in Japanese].

9) Kawasaki, T., Ceramics Japan, Vol. 20, pp. 195-203 (1985) [in Japanese].

10) Ikenoya, O., Sato, K., Soeno, Y. and Aoba, T., Jpn. J. OralBiol., Vol. 44, pp. 210-224 (2002) [in Japanese].

11) Kandori, K., Phosphorus Letter, No. 27, pp. 12-16 (1996) [in Japanese].

12) Makishima, A. and Aoki, H., "Bio Ceramics," Gihodo Shuppan (1984) pp. 59-60 [in Japanese]. 